Revista de BIOLOGía Tropical

\title{
Tracking the water fingerprints of Cocos Island: a stable isotope analysis of precipitation, surface water, and groundwater
}

\author{
José L. Corrales ${ }^{1}$, Ricardo Sánchez-Murillo ${ }^{1 *}$, Germain Esquivel-Hernández ${ }^{1}$, Esteban Herrera ${ }^{2}$ \\ \& Jan Boll ${ }^{3}$ \\ 1. Grupo de Investigación en Isótopos Estables, Escuela de Química, Universidad Nacional de Costa Rica, 86-3000 \\ Heredia, Costa Rica; ricardo.sanchez.murillo@una.cr \\ 2. Área de Conservación Marina Isla del Coco, 10102, San José, Costa Rica. \\ 3. University of Idaho, Moscow, Idaho 83844-3006, USA.
}

Received 22-II-2015. Corrected 28-IV-2015. Accepted 28-V-2015.

\begin{abstract}
The use of stable isotopes of water, both $\delta^{2} \mathrm{H}$ and $\delta^{18} \mathrm{O}$ has provided novel insights in hydrological studies, ecological applications, understanding climate variability, and reconstructing paleoclimate. However, information on the stable isotope composition of water in tropical marine island environments is normally scarce within the Central America Isthmus. Here, we present the first isotopic characterization of precipitation, surface water, and groundwater at Cocos Island, Costa Rica within the eastern tropical Pacific Ocean region. Our results show that the Cocos Island MWL can be described as: $\delta^{2} \mathrm{H}=8.39 \cdot \delta^{18} \mathrm{O}+13.3 ; \mathrm{r}^{2}=0.98(\mathrm{n}=29)$. Dry season rainfall events ranged from $-4.9 \% \delta^{18} \mathrm{O}$ up to $-2.4 \%{ }_{0} \delta^{18} \mathrm{O}$ with a mean $d$-excess of $13.2 \%$. By the beginning of May, the Intertropical Convergence Zone reaches Costa Rica resulting in a notable depletion in isotope ratios (up to $-10.4 \%{ }_{0} \delta^{18} \mathrm{O}$ and $\left.-76.2 \% \delta^{2} \mathrm{H}\right)$. During the wet season, $\delta^{18} \mathrm{O}$ composition averaged $-6.1 \%{ }_{0} \delta^{18} \mathrm{O}$ and $-38.5 \%$ $\delta^{2} \mathrm{H}$ with a mean $d$-excess of $9.9 \%$. HYSPLIT air mass back trajectories indicate a strong influence on the origin of precipitation of two main moisture transport mechanisms, the northeasterly (January-May) and southwesterly (May-November) trade winds. Small seasonal variations were observed in the isotopic composition of surface water throughout the year with mean values ranging from $-3.9 \% \delta^{18} \mathrm{O}$ (dry season, $\mathrm{n}=19$ ) up to $-4.8 \% \delta^{18} \mathrm{O}$ (wet season, $\mathrm{n}=13$ ). Groundwater samples exhibited a similar trend with more depleted composition during the wet season $\left(-5.2 \% \delta^{18} \mathrm{O}\right.$ and $\left.-29.8 \% \delta^{2} \mathrm{H}\right)$. Overall, the marine isotopic composition measured in meteoric water at Cocos Island serves to better delineate the isotopic contribution of Pacific moisture towards the Central America Isthmus. It also provides a valuable isotopic reference to discriminate from orographic distillation and Caribbean enriched rainfall inputs in continental studies. Rev. Biol. Trop. 64 (Suppl. 1): S105-S120. Epub 2016 February 01 .
\end{abstract}

Key words: Cocos Island, Eastern Tropical Pacific ocean, Intertropical Convergence Zone, stable isotope composition, HYSPLIT trajectories.

Cocos Island is located at $5^{\circ} 32^{\prime} \mathrm{N}-87^{\circ} 04^{\prime}$ $\mathrm{W}$ in the eastern tropical Pacific Ocean, approximately $530 \mathrm{~km} \mathrm{S-SW} \mathrm{of} \mathrm{Costa} \mathrm{Rica}$ and $680 \mathrm{~km}$ N-NE of the Galápagos Islands (Guzmán, \& Cortés, 2006) (Fig. 1). The island represents the summit of a seamount on the aseismic Cocos Ridge, a proposed trace of the Galápagos hot spot (Castillo et al., 1988; Rojas, \& Alvarado, 2012). Cocos Island was recognized in 1997 with the declaration as World Heritage Site by the UNESCO and
Wetland of International Importance by the Ramsar Convention in 1998 (Cortés, 2008) due to its pristine insular ecosystems represented by a great diversity of marine species (e.g. algae, octocorals, echinoderms) (Alvarado, \& Chiriboga, 2008; Breedy, \& Cortés; 2008; Fernández, 2008), sea birds (Montoya, 2008), and the particular confluence of oceanic currents (i.e. North Equatorial Countercurrent) and atmospheric low-level jets (Amador, Alfaro, Lizano, \& Magaña, 2006; Acuña-González, 


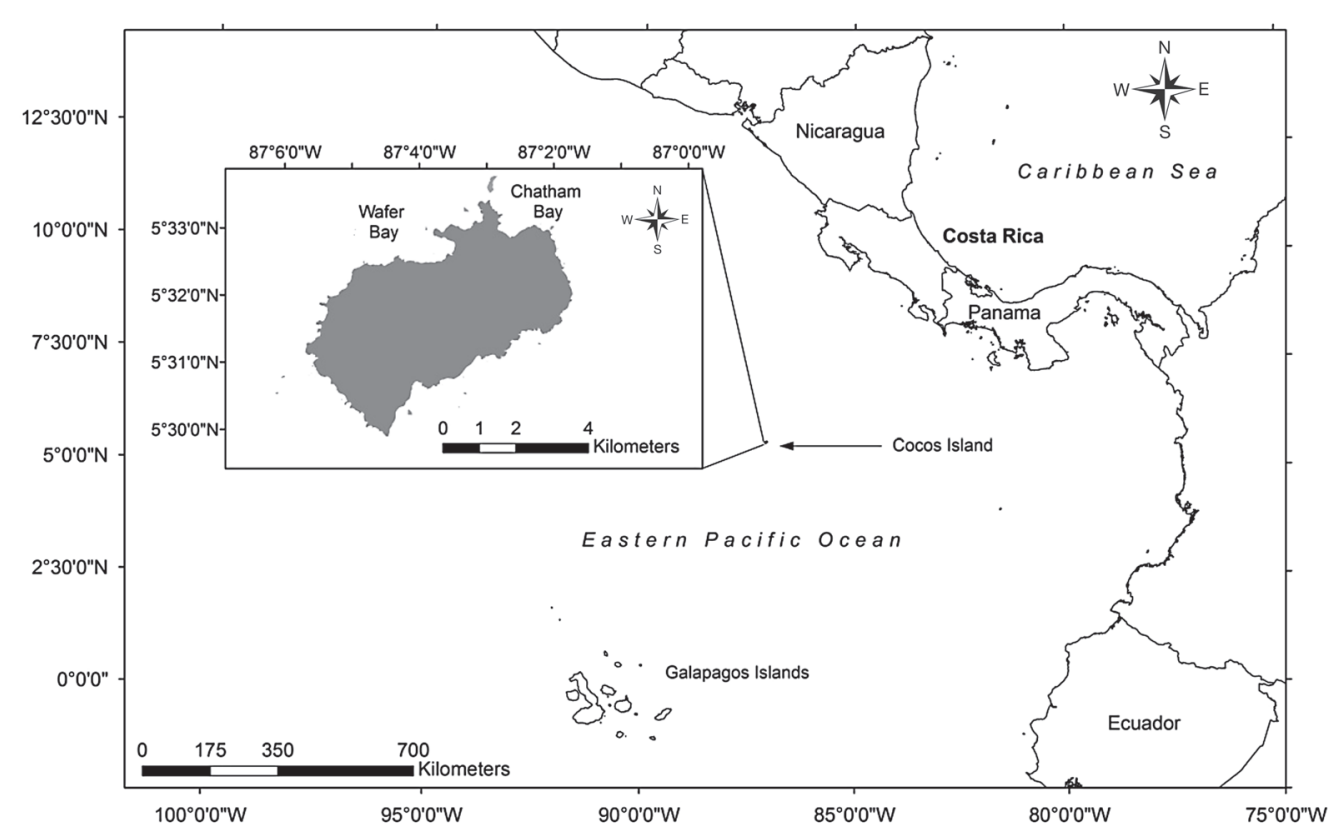

Fig. 1. Location of Cocos Island within the eastern tropical Pacific Ocean. The island is located 530km south-southwest of Costa Rica and 680km north-northeast of the Galápagos Islands.

García-Céspedes, Gómez-Ramírez, Vargas, \& Cortés, 2008; Alfaro, 2008), which results in the presence of warm surface waters from the western Pacific Ocean. The seasonal weather patterns at Cocos Island are mainly controlled by the meridian migration of the Intertropical Convergence Zone (ITCZ), while the interannual variations are driven by El Niño Southern Oscillation (ENSO), leading to three winds periods (December-April, May-August, and July-November) and a maximum rainfall regime varying from $4000 \mathrm{~mm}$ up to $6000 \mathrm{~mm}$ between May and October (Alfaro, 2008).

The use of stable isotopes of water, both $\delta^{2} \mathrm{H}$ and $\delta^{18} \mathrm{O}$, has provided novel insights in hydrological studies, ecological applications, understanding climate variability, and reconstructing paleoclimate (Johnson, \& Ingram, 2004; Lachniet, 2009a; Sturm, Zhang, \& Noone, 2010; Moerman et al., 2013). The development of affordable instrumentation based on laser spectroscopy has enhanced our ability to achieve greater temporal and spatial resolution of isotopic data (Berden, Peeters, \& Meijer, 2000; Wen et al., 2008; Gupta, Noone,
Galewsky, Sweeney, \& Vaughn, 2009; Munksgaard, Wurster, Bass, \& Bird, 2012) and is greatly helping in development of new research avenues to study the atmospheric water cycle (e.g. ${ }^{17} \mathrm{O}$-excess; Bernan, Levin, Landais, Li, \& Owano, 2013). In particular, collection and analyses techniques of these naturally occurring tracers have shown to be useful in elucidating atmospheric moisture sources and their implications for the hydrological cycle (Araguás-Araguás, Froehlich, \& Rozanski, 2000; Bowen, \& Revenaugh, 2003; Aggarwal et al., 2012; Risi, Noone, Frankenberg, \& Worden, 2013; Soderberg et al., 2013).

The global relationship between $\delta^{2} \mathrm{H}$ and $\delta^{18} \mathrm{O}$ in natural meteoric waters recognized by Craig (1961) and later defined as the Global Meteoric Water Line (GMWL: $\delta^{2} \mathrm{H}=8 \cdot \delta^{18} \mathrm{O}+10$ ) serves as a foundational reference to determine regional and local deviations (i.e. local meteoric water line, LMWL) from equilibrium processes. Factors, such as the trajectory of air masses, parental water vapor, latitude, altitude, precipitation amount, and distance from oceans, may also affect the spatial and temporal 
variations of $\delta^{2} \mathrm{H}$ and $\delta^{18} \mathrm{O}$ ratios in precipitation (Rozanski, Sonntag, \& Münnich, 1982). Water losses due to evaporation, the incorporation of recycled atmospheric moisture, and mixing between isotopically-distinct reservoirs leave a unique water fingerprint that can be used to understand rainfall-runoff processes (Birkel, Soulsby, Tezlaff, Dunn, \& Spezia, 2012), complex water flow paths (McGlynn, McDonnel, \& Brammer, 2002), groundwater to surface water connectivity (Tetzlaff, \& Soulsby, 2008; Speed, Tezlaff, Soulsby, Hrachowitz, \& Waldron, 2010; Wassenaar, Athanasopoulos, \& Hendry, 2011), baseflow recession analysis (Sánchez-Murillo, Brooks, Elliot, \& Boll, 2015), and isotope-based paleoclimate-reconstructions (Moerman et al., 2013).

Light stable isotope compositions of tropical meteoric waters have proven to be an important indicator of modern climate variability (Araguás-Araguás, Froehlich, \& Rozanski, 1998; Vuille, Bradley, \& Keimig, 2000; Vuille et al., 2003; Cobb, Adkins, Partin, \& Clark, 2007; Lachniet, 2009b; Lachniet, \& Paterson, 2009, Ishizaki et al., 2012; Moerman et al., 2013). In particular, $\delta^{18} \mathrm{O}$ values have provided novel insights into El Niño/Southern Oscillation dynamics (Vuille, \& Werner, 2005; Ichinayagi, \& Yamanaka, 2005; Lachniet, Paterson, Burns, Asmerom, \& Polyak, 2007; Panarello, \& Dapeña, 2009). Despite these advances, stable isotope research in Costa Rica has been limited, especially in maritime environments. To our knowledge, this study represents the first water isotope characterization of a marine island within the eastern Pacific Ocean boundary of Costa Rica. The main objectives of this study are to a) provide a description of $\delta^{18} \mathrm{O}, \delta^{2} \mathrm{H}$, and deuterium excess (i.e. $d$-excess) values in precipitation, surface water, and groundwaters of Cocos Island that may contribute to water resources and preservation management plans of the island, and b) contribute to the understanding of water vapor transport mechanisms and isotopic gradients from the ETP towards the Central America Isthmus.

\section{MATERIALS AND METHODS}

Precipitation samples: Weekly samples at Wafer Bay (n=29) (Fig. 2) were collected between March and October 2014 using a passive rainfall collector which consists of a plastic funnel (diameter $=10 \mathrm{~cm}$ ) connected to a $4 \mathrm{~L}$ opaque high density polyethylene (HDPE) container. Samples were stored at Cocos Island Marine Conservation Area facilities and shipped every two months to the port of Puntarenas, Costa Rica on the Wind Dancer vessel (Okeanos, Costa Rica). A $2 \mathrm{~cm}$ layer of mineral oil was added prior collection to prevent fractionation according with standard sampling protocols (IAEA, 2014). The mineral oil was later separated using a 250-500 $\mathrm{mL}$ separatory funnel. Prepared samples were stored upside down at $5^{\circ} \mathrm{C}$ in HDPE bottles with conic and polyseal inserts and parafilm seals until analysis.

Surface and groundwaters samples: Two field campaigns were conducted (March 17-22 and September 16-20,2014) to collect surface water $(n=32)$ and groundwater $(n=2)$ samples across the island depending on the accessibility of the sites and availability of park rangers to accompany the field expeditions; therefore, freshwater sample collection was limited to the north-eastern portion of the island (Fig. 2) within two main watersheds: Genio and Chatham. The groundwater samples were collected at the only existing well on the island (Fig. 2). During the second field campaign, in situ values of $\mathrm{pH}$, water temperature $\left({ }^{\circ} \mathrm{C}\right)$, and electrical conductivity $(\mu \mathrm{S} / \mathrm{cm})$ were measured with a handheld multiparameter probe model HI 9813-6 (Hanna Instruments, USA).

Fractionation experiment: A duplicate pan evaporation experiment was conducted at Cocos Island on September 18, 2014 with the aim of analyze the isotopic fractionation under marine conditions. Two stainless steel cylindrical pans (diameter $=15.3 \mathrm{~cm}$ ) were filled with 


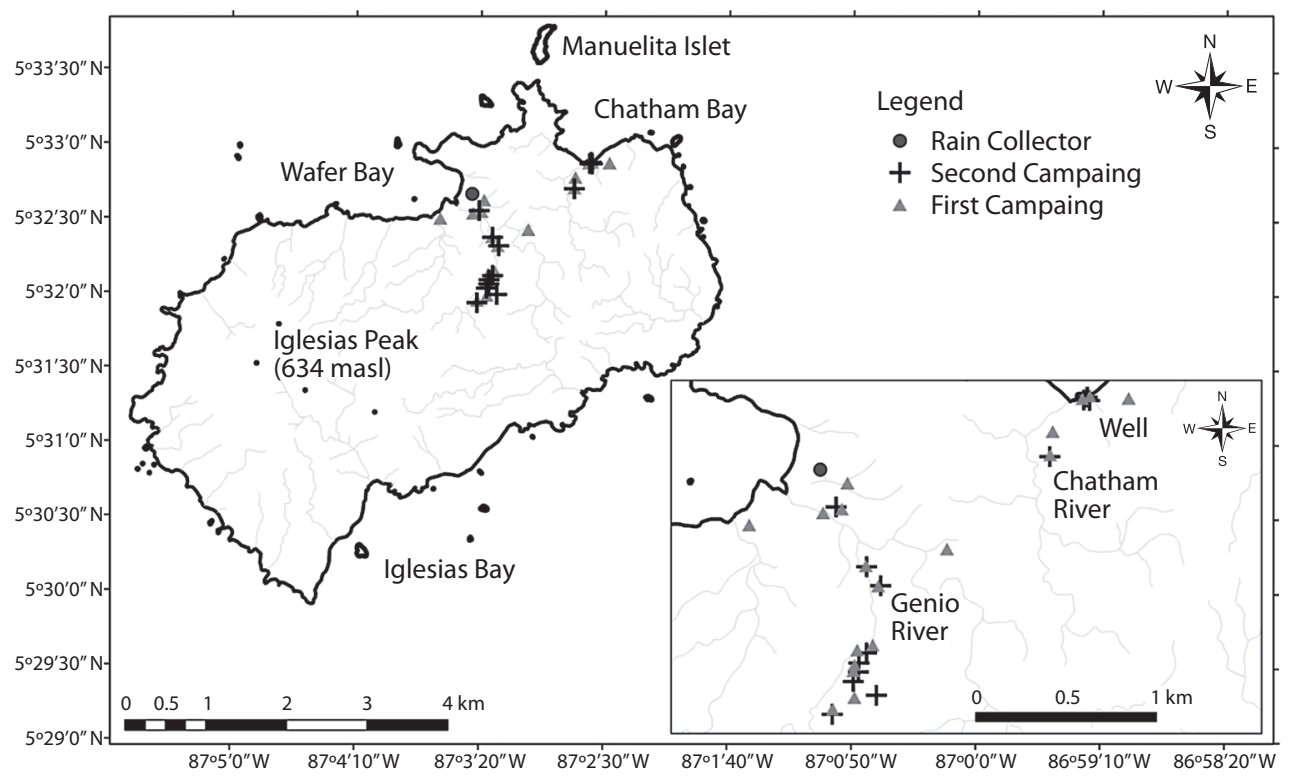

Fig. 2. Sampling sites location at the Cocos Island. The black circle denotes the position of the rainfall collector at Wafer Bay. Gray triangles represent the sampling points during the first field expedition (March 17-22, 2014) and the gray crosses correspond to the second field expedition (September 16-20, 2014). The inset shows in detail the two main watersheds sampled: Genio and Chatham.

$370.7 \mathrm{~mL}$ of local groundwater $\left(\delta^{18} \mathrm{O}=-5.1 \%\right.$, $\delta^{2} \mathrm{H}=-29.5 \%$ ). The pans were exposed to solar radiation for eight hours (from 8:00 until 17:00). A $2 \mathrm{~mL}$ sample was taken from each pan every 20 min during the first hour, every $30 \mathrm{~min}$ during the subsequent four hours, and every $60 \mathrm{~min}$ during the last three hours. The samples were sealed with parafilm and stored at $5^{\circ} \mathrm{C}$ until analysis. The mean evaporation rate was $5.56 \mathrm{~g} / \mathrm{hr}$ (i.e. $0.281 \mathrm{~mol} / \mathrm{hr}$ ). The residual volume of water during evaporation was calculated using the decrease in height of the water column and the cylinder area. During the experiment, air temperature and relative humidity were measured using a LW301 weather sensor kit (Oregon Scientific, USA). Observed isotope data was simulated with a four parameter sigmoid function as follows:

$$
\mathrm{y}=\mathrm{y}_{\mathrm{o}}+\frac{a}{1+\mathrm{e}^{-\left(\frac{x-x_{o}}{b}\right)}}
$$

where $y$ is the observed $\delta^{18} \mathrm{O}$ and d-excess values in the experiment, $y_{0}$ is the sigmoid function intercept, and $a$ and $b$ are fitting parameters. The sigmoid function was selected to simulate the isotopic fractionation of water during evaporation (Cappa, Hendricks, DePaolo, \& Cohen, 2003).

Stable isotope analyses: Stable isotope analyses were conducted at the Chemistry School of the National University (Heredia, Costa Rica) using a Cavity Ring Down Spectroscopy (CRDS) water isotope analyzer L2120-i (Picarro, USA). Ratios of $\delta^{18} \mathrm{O} / \delta^{16} \mathrm{O}$ and $\delta^{2} \mathrm{H} / \delta^{1} \mathrm{H}$ are expressed in delta units $(\%$, parts per mil) relative to Vienna Standard Mean Ocean Water (V-SMOW). The analytical analyzer precision was $0.07 \% \delta^{18} \mathrm{O} / \delta^{16} \mathrm{O}$ and $0.25 \% \delta^{2} \mathrm{H} / \delta^{1} \mathrm{H}$.

Meteorological data and HYSPLIT air mass back trajectories: Daily meteorological data (i.e. precipitation, air temperature, relative humidity, and wind speed) were provided by the Cocos Island Marine Conservation Area and the National Meteorological Institute. The 
monitoring station is located at Chatham Bay. Only daily records from March 17 through September 12, 2014 were available. The influence of atmospheric trajectory on meteoric isotopic composition was studied using the HYSPLIT model (Draxler, \& Rolph, 2014) (http://ready. arl.noaa.gov/HYSPLIT.php) developed by the National Oceanic and Atmospheric Administration (NOAA). The HYSPLIT model uses a three-dimensional Lagrangian air mass velocity algorithm to determine the position of the air mass and reports these values at an hourly time-resolution over the trajectory (Soderberg et al., 2013). Air parcel trajectories were modeled backwards in time (i.e. according to the weekly isotopic sampling intervals). To compute a trajectory, the HYSPLIT model requires a starting time, location, and altitude as well as NOAA meteorological data files (e.g. GDAS, global data assimilation system, 2006-present). Although it has been recognized (Alfaro, 2008) that a particular rainless period is absent at Cocos Island throughout the year, the trajectories were divided into two main groups to facilitate the analysis: dry season (JanuaryApril) and wet season (May-November).

\section{RESULTS}

$\delta^{2} \mathbf{H}$ and $\delta^{18} \mathrm{O}$ in precipitation: The linear relationship of $\delta^{2} \mathrm{H}$ and $\delta^{18} \mathrm{O}$ ratios of precipitation samples collected at Cocos Island $(n=29)$ is presented in Figure 3 and compared to the GMWL and Costa Rica MWL (Sánchez et al., 2013). The $\delta^{2} \mathrm{H}$ and $\delta^{18} \mathrm{O}$ ratios of precipitation at Cocos Island ranged from $-79.2 \%$ to $-5.9 \%$ and $-10.4 \%$ to $-2.0 \%$, respectively. A least squares regression of the precipitation isotope data resulted in a highly significant LMWL: $\delta^{2} \mathrm{H}=8.39 \cdot \delta^{18} \mathrm{O}+13.3 ; \mathrm{r}^{2}=0.98(\mathrm{n}=29)$. During the sampling period, weather conditions at Cocos Island exhibited a cumulative precipitation of $5640 \mathrm{~mm}, 80 \%$ of total rainfall was received between May and September,

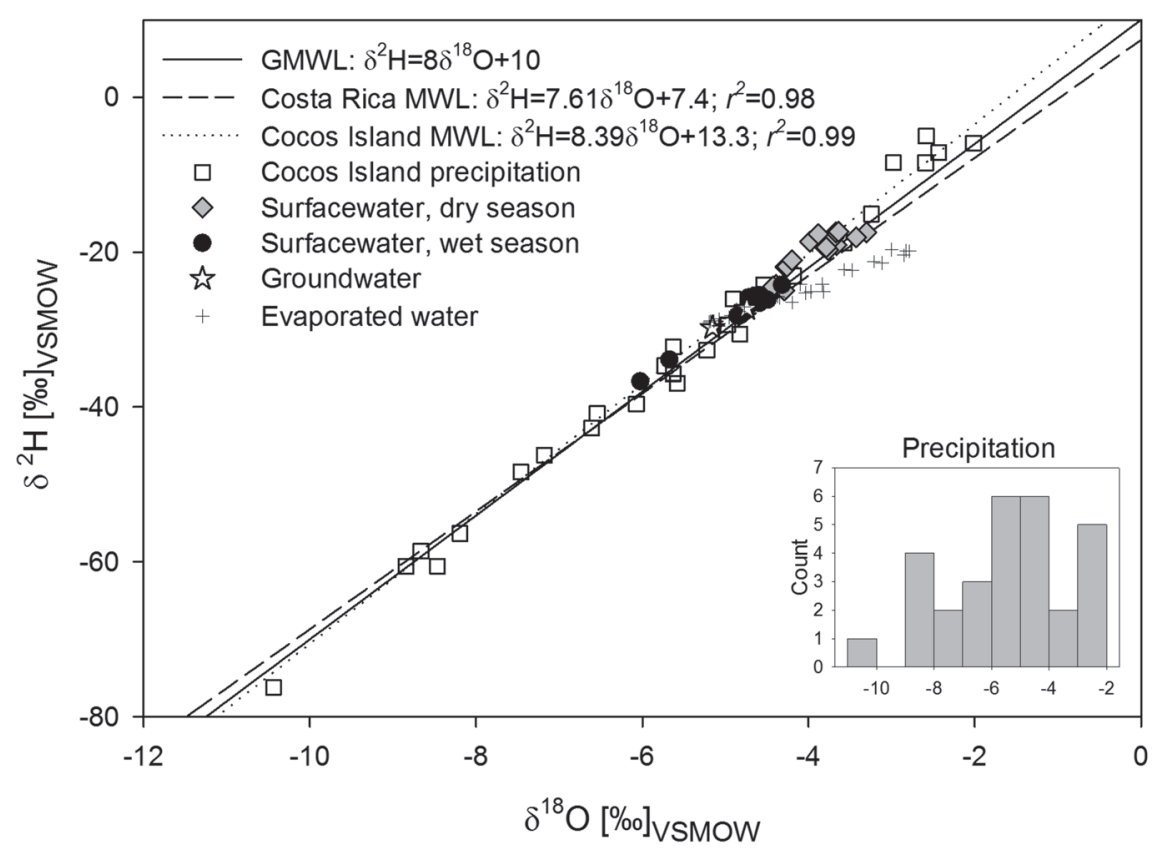

Fig. 3. Cocos Island meteoric water lines. The MWL at Cocos Island can be defined as: $\delta^{2} \mathrm{H}=8.28 \cdot \delta^{18} \mathrm{O}+11.7$. The GMWL and Costa Rica continental MWL (Sánchez-Murillo et al., 2013) are shown as reference. Open squares denote rainfall samples. The gray rhomboids and black circles represent the freshwater samples collected during the dry and wet season, respectively. Black crosses correspond to evaporated water from the pan experiment. The white stars represent the two groundwater samples. The inset shows the distribution of $\delta^{18} \mathrm{O}$ composition in precipitation during 2014. 
2014 (Fig. 4A). Mean surface air temperature, relative humidity, and wind speed were $26.2^{\circ} \mathrm{C}$, $83.2 \%$, and $7.9 \mathrm{~km} / \mathrm{h}$, respectively (Fig. 4A and $4 \mathrm{~B}$ ).

Isotope ratios in dry season rainfall (January-April) are mostly related to enriched events (Fig. 4C, Table 1) with a mean $\delta^{18} \mathrm{O}$ of $-3.3 \%$. By mid-May, when the ITCZ reaches Costa Rica, a notable depletion (up to $-10.4 \% \delta^{18} \mathrm{O}$ ) was observed (Fig. 4C). Northward shifting of the ITCZ and the prevalence of sea surface temperature anomalies up to $1.0^{\circ} \mathrm{C}$ within the ENSO regions 3.4 and 3 during 2014 (NOAA,
Climate Prediction Center, 2014) resulted in a greater isotopic variability throughout the wet season. Deuterium excess values ranged from $+7.2 \%$ up to $+12.8 \%$ with a mean of 9.95 \%o (Fig. 4D). A Spearman rank order correlation analysis revealed no significant correlations between $\delta^{18} \mathrm{O}$ and rainfall amount $(-0.26$, $\mathrm{p}=0.293)$, relative humidity $(-0.014, \mathrm{p}=0.954)$, and surface air temperature $(0.13, \mathrm{p}=0.609)$.

Physical-chemical parameters, $\delta^{2} \mathbf{H}$, and $\delta^{18} \mathrm{O}$ in surface water and groundwater: Figure 5 shows the spatial distribution of $\mathrm{pH}$,
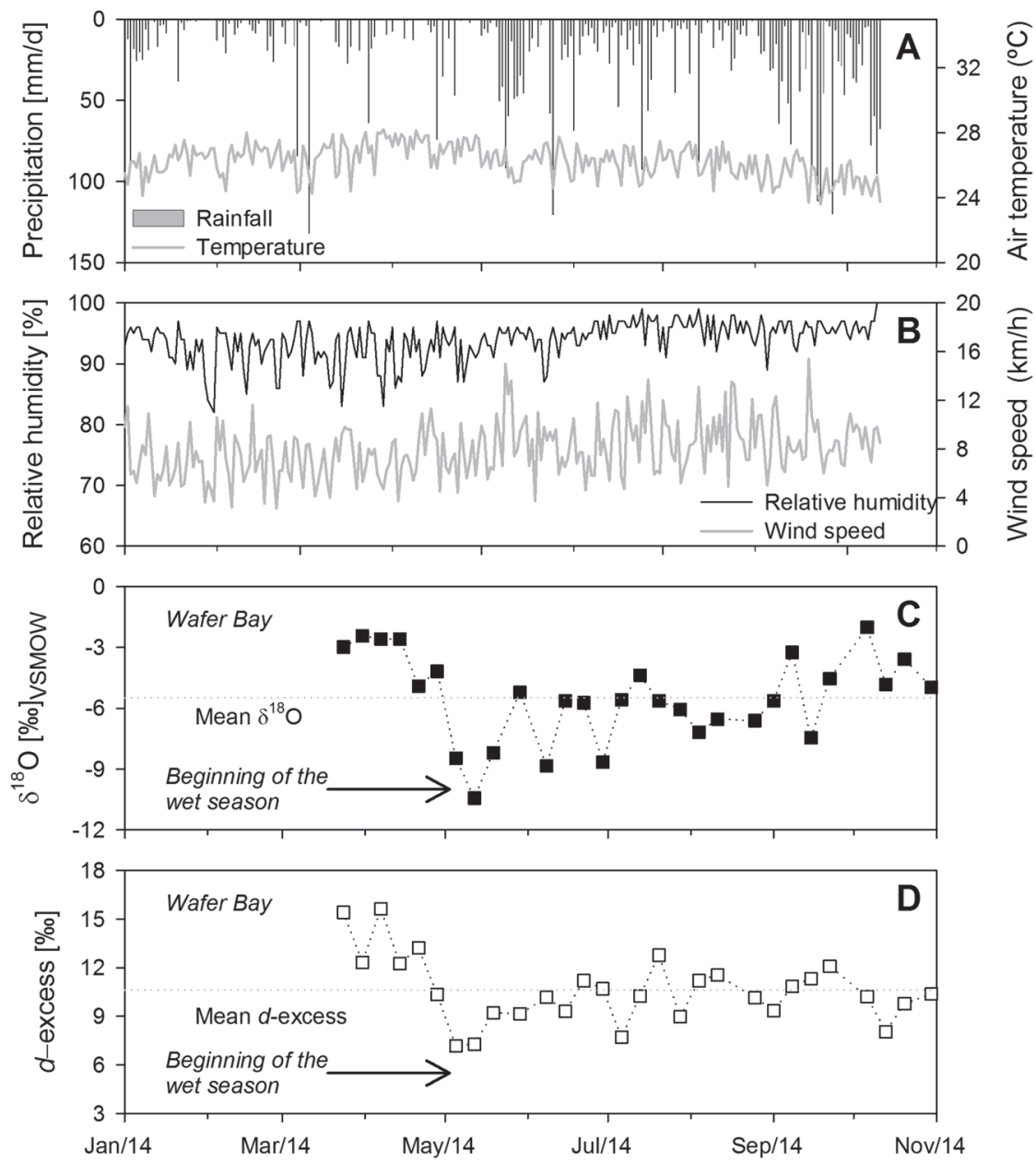

Fig. 4. Time series of observed meteorological variables and isotope composition at Cocos Island during 2014. (A) Precipitation $(\mathrm{mm} / \mathrm{d})$ and surface air temperature $\left({ }^{\circ} \mathrm{C}\right) ;(\mathrm{B})$ relative humidity $(\%)$ and maximum wind speed $(\mathrm{km} / \mathrm{hr}),(\mathrm{C})$ $\delta^{18} \mathrm{O}(\%)$ in precipitation; (D) d-excess (\%o). Black arrows denote the transition from the dry season (Dec-April) to the wet season (May-Nov.). 
TABLE 1

Summary of meteoric water isotope composition and meteorological data at Cocos Island from March 17 through October 30, 2014

\begin{tabular}{|c|c|c|c|c|c|c|c|c|c|}
\hline Initial Date & Final Date & $\delta^{18} \mathrm{O}(\%)$ & SD (\%o) & $\delta^{2} \mathrm{H}(\%)$ & SD (\%) & d-excess $(\% 0)$ & $\mathrm{P}(\mathrm{mm})$ & $\mathrm{T}\left({ }^{\circ} \mathrm{C}\right)$ & RH (\%) \\
\hline \multicolumn{10}{|c|}{ Dry season } \\
\hline $3 / 17 / 14$ & $3 / 24 / 14$ & -2.98 & 0.10 & -8.44 & 0.11 & 15.4 & 128 & 26.8 & 79.8 \\
\hline $3 / 24 / 14$ & $3 / 31 / 14$ & -2.44 & 0.06 & -7.16 & 0.24 & 12.3 & 102 & 27.4 & 78.6 \\
\hline $3 / 31 / 14$ & $4 / 7 / 14$ & -2.58 & 0.07 & -5.04 & 0.19 & 15.6 & 20 & 27.5 & 79.4 \\
\hline $4 / 7 / 14$ & $4 / 14 / 14$ & -2.59 & 0.11 & -8.49 & 0.14 & 12.3 & 25 & 27.5 & 80.9 \\
\hline $4 / 14 / 14$ & $4 / 21 / 14$ & -4.91 & 0.11 & -26.05 & 0.43 & 13.2 & 134 & 26.8 & 82.7 \\
\hline $4 / 21 / 14$ & $4 / 28 / 14$ & -4.18 & 0.09 & -23.09 & 0.21 & 10.3 & 50 & 27.2 & 80.0 \\
\hline Mean & & -3.28 & 0.09 & -13.05 & 0.22 & 13.2 & 77 & 27.2 & 80.2 \\
\hline Maximum & & -2.44 & 0.11 & -5.04 & 0.43 & 15.6 & 134 & 27.5 & 82.7 \\
\hline Minimum & & -4.91 & 0.06 & -26.05 & 0.11 & 10.3 & 20 & 26.8 & 78.6 \\
\hline \multicolumn{10}{|c|}{ Wet season } \\
\hline $4 / 28 / 14$ & $5 / 5 / 14$ & -8.46 & 0.04 & -60.54 & 0.22 & 7.2 & 26 & 26.8 & 83.3 \\
\hline $5 / 5 / 14$ & $5 / 12 / 14$ & -10.44 & 0.14 & -76.22 & 0.34 & 7.3 & 310 & 26.2 & 84.5 \\
\hline $5 / 12 / 14$ & $5 / 19 / 14$ & -8.19 & 0.07 & -56.33 & 0.16 & 9.2 & 208 & 25.8 & 85.9 \\
\hline $5 / 22 / 14$ & $5 / 29 / 14$ & -5.22 & 0.07 & -32.64 & 0.33 & 9.1 & 219 & 26.7 & 82.6 \\
\hline $5 / 30 / 14$ & $6 / 8 / 14$ & -8.84 & 0.10 & -60.59 & 0.18 & 10.2 & 167 & 26.1 & 86.2 \\
\hline $6 / 8 / 14$ & $6 / 15 / 14$ & -5.63 & 0.07 & -35.74 & 0.48 & 9.3 & 81 & 26.3 & 86.9 \\
\hline $6 / 15 / 14$ & $6 / 22 / 14$ & -5.73 & 0.11 & -34.67 & 0.15 & 11.2 & 124 & 26.3 & 87.1 \\
\hline $6 / 22 / 14$ & $6 / 29 / 14$ & -8.66 & 0.08 & -58.61 & 0.25 & 10.7 & 220 & 25.6 & 85.9 \\
\hline $6 / 29 / 14$ & $7 / 6 / 14$ & -5.58 & 0.07 & -36.94 & 0.39 & 7.7 & 75 & 26.5 & 83.9 \\
\hline $7 / 6 / 14$ & $7 / 13 / 14$ & -4.37 & 0.05 & -24.73 & 0.14 & 10.3 & 143 & 26.6 & 85.4 \\
\hline $7 / 13 / 14$ & $7 / 20 / 14$ & -5.63 & 0.05 & -32.26 & 0.31 & 12.8 & 123 & 25.9 & 84.1 \\
\hline $7 / 20 / 14$ & $7 / 28 / 14$ & -6.07 & 0.02 & -39.59 & 0.16 & 9.0 & 101 & 26.0 & 85.0 \\
\hline $7 / 28 / 14$ & $8 / 4 / 14$ & -7.18 & 0.06 & -46.22 & 0.15 & 11.2 & 66 & 25.6 & 85.1 \\
\hline $8 / 4 / 14$ & $8 / 11 / 14$ & -6.54 & 0.06 & -40.80 & 0.34 & 11.5 & 203 & 25.4 & 84.9 \\
\hline $8 / 11 / 14$ & $8 / 25 / 14$ & -6.61 & 0.07 & -42.72 & 0.28 & 10.2 & 592 & 25.6 & 85.1 \\
\hline $8 / 25 / 14$ & $9 / 1 / 14$ & -5.63 & 0.05 & -35.69 & 0.29 & 9.3 & 243 & 25.1 & 86.8 \\
\hline $9 / 1 / 14$ & $9 / 8 / 14$ & -3.24 & 0.05 & -15.09 & 0.27 & 10.8 & 148 & 25.2 & 86.8 \\
\hline 9/8/14 & $9 / 15 / 14$ & -7.46 & 0.07 & -48.37 & 0.18 & 11.3 & 305 & 24.6 & 89.8 \\
\hline $9 / 15 / 14$ & $9 / 22 / 14$ & -4.54 & 0.06 & -24.22 & 0.20 & 12.1 & 147 & 25.2 & 95.6 \\
\hline $9 / 22 / 14$ & $10 / 6 / 14$ & -2.01 & 0.08 & -5.91 & 0.18 & 10.2 & 335 & 25.3 & 95.9 \\
\hline $10 / 6 / 14$ & $10 / 13 / 14$ & -4.83 & 0.10 & -30.56 & 0.11 & 8.1 & 167 & 25.3 & 95.4 \\
\hline $10 / 13 / 14$ & $10 / 20 / 14$ & -3.57 & 0.11 & -18.80 & 0.23 & 9.8 & 55 & 25.9 & 94.4 \\
\hline $10 / 20 / 14$ & $10 / 30 / 14$ & -4.97 & 0.10 & -29.42 & 0.39 & 10.4 & 98 & 25.1 & 95.1 \\
\hline $10 / 31 / 14$ & $11 / 14 / 14$ & -3.11 & 0.04 & -16.75 & 0.22 & 8.09 & 489 & 25.2 & 96.7 \\
\hline $11 / 15 / 14$ & $11 / 22 / 14$ & -4.27 & 0.07 & -26.80 & 0.28 & 7.34 & 88 & 25.5 & 96.9 \\
\hline $11 / 23 / 14$ & $11 / 29 / 14$ & -3.04 & 0.07 & -14.77 & 0.14 & 9.53 & 69 & 25.9 & 95.0 \\
\hline $11 / 30 / 14$ & $12 / 6 / 14$ & -2.74 & 0.06 & -13.20 & 0.24 & 8.74 & --- & --- & --- \\
\hline $12 / 7 / 14$ & $12 / 13 / 14$ & -4.90 & 0.05 & -30.51 & 0.27 & 8.71 & --- & --- & --- \\
\hline $12 / 14 / 14$ & $12 / 21 / 14$ & -3.25 & 0.08 & -17.69 & 0.09 & 8.30 & --- & --- & --- \\
\hline $12 / 22 / 14$ & $12 / 29 / 14$ & -4.08 & 0.07 & -23.27 & 0.22 & 9.39 & --- & --- & --- \\
\hline Mean & & -5.49 & 0.07 & -34.32 & 0.24 & 9.63 & 185 & 25.8 & 88.6 \\
\hline Maximum & & -2.01 & 0.14 & -5.04 & 0.48 & 15.62 & 592 & 26.8 & 96.9 \\
\hline Minimum & & -10.44 & 0.02 & -76.22 & 0.09 & 7.17 & 26 & 24.6 & 82.6 \\
\hline
\end{tabular}



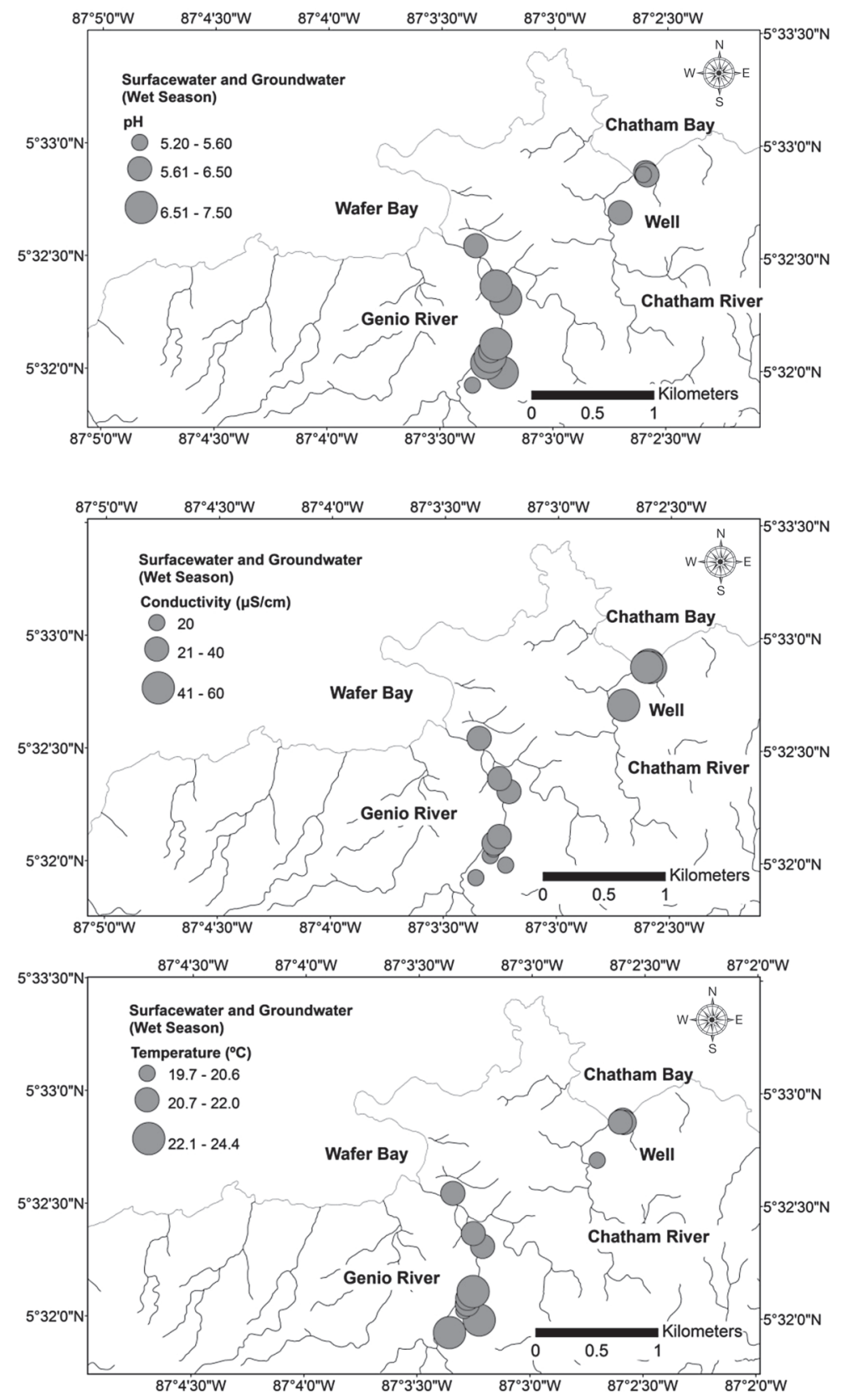

Fig. 5. Spatial distribution of $\mathrm{pH}$, electrical conductivity $(\mu \mathrm{S} / \mathrm{cm})$, and water temperature $\left({ }^{\circ} \mathrm{C}\right)$ in surface water and groundwater at Cocos Island during September, 2014.

electrical conductivity, and water temperature in surface water and ground water within the Genio and Chatham rivers during the wet season. In general, surface water within the Chatham watershed due to its proximity to the coast exhibited greater conductivity values (up to $60 \mu \mathrm{S} / \mathrm{cm}$ ); however, no salinity intrusion was observed within the freshwater systems. Water temperature and $\mathrm{pH}$ values ranged from $19.7-24.4^{\circ} \mathrm{C}$ and $5.2-7.5$, respectively. 
The relationship of $\delta^{2} \mathrm{H}$ and $\delta^{18} \mathrm{O}$ ratios in freshwater at Cocos Island and spatial variability are presented in Figures 3 and 6. During the dry season, lower relative humidity and greater air surface temperature facilitate surface water evaporation resulting in enriched isotope ratios ranging from $-3.3 \% \delta^{18} \mathrm{O}$ up to $-4.4 \% \delta^{18} \mathrm{O}$ (Table 2) with a linear regression of $\delta^{2} \mathrm{H}=6.55 \cdot \delta^{18} \mathrm{O}+5.59 ; \mathrm{r}^{2}=0.79(\mathrm{n}=19)$. During the wet season, isotope values ranged from $-6.0 \% \delta^{18} \mathrm{O}$ up to $-4.3 \% \delta^{18} \mathrm{O}$ (Table 3 ) with a linear regression of $\delta^{2} \mathrm{H}=7.35 \cdot \delta^{18} \mathrm{O}+7.70$;

TABLE 2

Summary of freshwater sampling locations and isotope composition during the first field expedition between March 17-22, 2014

\begin{tabular}{rccccccccc}
$\begin{array}{r}\text { Sample } \\
\text { Code }\end{array}$ & $\begin{array}{c}\text { Latitude } \\
(\text { dec.deg})\end{array}$ & $\begin{array}{c}\text { Longitude } \\
(\text { dec.deg})\end{array}$ & Elevation $(\mathrm{m})$ & $\delta^{18} \mathrm{O}(\%)$ & SD $(\%)$ & $\delta^{2} \mathrm{H}(\%)$ & SD $(\%)$ & d-excess $(\%)$ \\
GW-IS-01 & 5.5480 & -87.0432 & 12 & -4.74 & 0.05 & -27.27 & 0.34 & 10.7 \\
SF-IS-001 & 5.5424 & -87.0554 & 11 & -3.72 & 0.11 & -18.90 & 0.27 & 10.9 \\
SF-IS-002 & 5.5404 & -87.0502 & 48 & -4.29 & 0.11 & -24.96 & 0.20 & 9.4 \\
SF-IS-003 & 5.5396 & -87.0542 & 57 & -3.66 & 0.12 & -19.10 & 0.29 & 10.2 \\
SF-IS-004 & 5.5386 & -87.0536 & 69 & -3.81 & 0.11 & -19.29 & 0.29 & 11.2 \\
SF-IS-005 & 5.5357 & -87.0539 & 132 & -3.30 & 0.12 & -17.45 & 0.32 & 9.0 \\
SF-IS-006 & 5.5354 & -87.0547 & 160 & -3.43 & 0.10 & -18.08 & 0.35 & 9.4 \\
SF-IS-007 & 5.5347 & -87.0548 & 150 & -3.70 & 0.06 & -18.11 & 0.25 & 11.5 \\
SF-IS-008 & 5.5344 & -87.0549 & 148 & -3.76 & 0.07 & -19.75 & 0.10 & 10.4 \\
SF-IS-009 & 5.5330 & -87.0548 & 165 & -3.67 & 0.12 & -17.44 & 0.23 & 12.0 \\
SF-IS-010 & 5.5325 & -87.0559 & 188 & -3.64 & 0.04 & -17.34 & 0.18 & 11.8 \\
SF-IS-011 & 5.5437 & -87.0552 & 31 & -4.28 & 0.11 & -21.89 & 0.08 & 12.3 \\
SF-IS-012 & 5.5479 & -87.0435 & 26 & -4.28 & 0.06 & -21.96 & 0.20 & 12.3 \\
SF-IS-013 & 5.5480 & -87.0431 & 14 & -4.26 & 0.07 & -21.88 & 0.17 & 12.2 \\
SF-IS-014 & 5.5479 & -87.0412 & 29 & -4.39 & 0.07 & -24.24 & 0.26 & 10.9 \\
SF-IS-015 & 5.5479 & -87.0412 & 29 & -4.43 & 0.06 & -24.45 & 0.25 & 11.0 \\
SF-IS-016 & 5.5422 & -87.0564 & 22 & -4.20 & 0.14 & -21.06 & 0.12 & 12.5 \\
SF-IS-017 & 5.5451 & -87.0451 & 118 & -3.98 & 0.09 & -18.66 & 0.16 & 13.2 \\
SF-IS-018 & 5.5463 & -87.0449 & 99 & -3.88 & 0.07 & -17.69 & 0.18 & 13.4 \\
SF-IS-019 & 5.5416 & -87.0600 & 15 & -3.79 & 0.08 & -19.42 & 0.17 & 10.9 \\
\hline
\end{tabular}

TABLE 3

Summary of freshwater sampling locations, physical-chemical parameters, and isotope composition during the second field expedition between September 16-20, 2014

\begin{tabular}{cccccccccccc}
$\begin{array}{c}\text { Sample } \\
\text { Code }\end{array}$ & $\begin{array}{c}\text { Latitude } \\
(\text { dec.deg})\end{array}$ & $\begin{array}{c}\text { Longitude } \\
(\text { dec.deg})\end{array}$ & $\begin{array}{c}\text { Elevation } \\
(\mathrm{m})\end{array}$ & $\mathrm{T}\left({ }^{\circ} \mathrm{C}\right)$ & $\mathrm{pH}$ & $\begin{array}{c}\mathrm{EC} \\
(\mu \mathrm{S} / \mathrm{cm})\end{array}$ & $\begin{array}{c}\delta^{18} \mathrm{O} \\
(\%)\end{array}$ & $\begin{array}{c}\mathrm{SD} \\
(\%)\end{array}$ & $\begin{array}{c}\delta^{2} \mathrm{H} \\
(\%)\end{array}$ & $\begin{array}{c}\text { SD } \\
(\%)\end{array}$ & $\begin{array}{c}\mathrm{d} \text {-excess } \\
(\%)\end{array}$ \\
GW-IS-02 & 5.5480 & -87.0432 & 2 & 21.4 & 5.6 & 60 & -5.16 & 0.08 & -29.76 & 0.33 & 11.49 \\
SF-IS-019 & 5.5322 & -87.0559 & 190 & 24.4 & 7.1 & 20 & -4.64 & 0.06 & -25.64 & 0.22 & 11.50 \\
SF-IS-020 & 5.5332 & -87.0537 & 210 & 24.4 & 7.1 & 20 & -4.72 & 0.08 & -25.88 & 0.15 & 11.89 \\
SF-IS-021 & 5.5339 & -87.0549 & 210 & 20.6 & 7.1 & 20 & -4.64 & 0.09 & -26.25 & 0.10 & 10.87 \\
SF-IS-022 & 5.5343 & -87.0546 & 147 & 21.0 & 6.2 & 20 & -4.75 & 0.06 & -27.59 & 0.15 & 10.40 \\
SF-IS-023 & 5.5348 & -87.0546 & 141 & 21.6 & 7.4 & 40 & -4.32 & 0.08 & -24.26 & 0.19 & 10.29 \\
SF-IS-024 & 5.5353 & -87.0542 & 133 & 23.0 & 7.5 & 30 & -4.63 & 0.05 & -26.01 & 0.26 & 11.00 \\
SF-IS-025 & 5.5386 & -87.0535 & 71 & 22.0 & 7.0 & 30 & -4.60 & 0.11 & -25.58 & 0.20 & 11.23 \\
SF-IS-026 & 5.5396 & -87.0542 & 58 & 21.3 & 6.3 & 30 & -4.49 & 0.03 & -26.20 & 0.11 & 9.73 \\
SF-IS-027 & 5.5425 & -87.0557 & 20 & 22.0 & 6.5 & 30 & -4.59 & 0.07 & -26.61 & 0.26 & 10.12 \\
SF-IS-031 & 5.5450 & -87.0451 & 108 & 19.7 & 6.2 & 60 & -5.67 & 0.05 & -33.91 & 0.15 & 11.47 \\
SF-IS-032 & - & - & - & - & - & - & -6.02 & 0.08 & -36.71 & 0.13 & 11.47 \\
SF-IS-033 & 5.5478 & -87.0431 & 12 & 21.9 & 6.5 & 50 & -4.81 & 0.07 & -28.15 & 0.20 & 10.34 \\
SF-IS-034 & 5.5479 & -87.0434 & 15 & 21.3 & 5.2 & 50 & -4.85 & 0.07 & -28.25 & 0.14 & 10.56 \\
\hline
\end{tabular}


$r^{2}=0.97(n=13)$. Overall, the Genio River presented more depleted waters than the Chatham River probably due to the presence of a large fraction of forested area preventing the direct influence of solar radiation (Fig. 6).

A small seasonal variation was observed in groundwater composition, which fluctuated from $-4.74 \% \delta^{18} \mathrm{O}$ (dry season) to $-5.16 \%$ $\delta^{18} \mathrm{O}$ (wet season). Commonly, groundwater isotopic composition tends to represent a composite composition of the infiltrated meteoric waters, at Cocos Island the mean annual $\delta^{18} \mathrm{O}$ was $-5.49 \%$, therefore, it is possible that a) rain water experiences small evaporation before percolation and $b$ ) the water table is really shallow allowing evaporation. Pan evaporation data (Fig. 7) show an enrichment of approximately $2 \%$ in a fractionation period of $8 \mathrm{hr}$ with a mean evaporation rate of $5.56 \mathrm{~g} /$ hr corresponding to $20 \%$ of the initial water volume (Fig. 7A). During the experiment, the $d$-excess changed from $+12.6 \%$ to $+2.4 \%$ (Fig. 7B). The evaporation $\delta^{2} \mathrm{H}-\delta^{18} \mathrm{O}$ relationships resulted in slopes ranging from +3.79 to +4.14 and intercepts from -9.62 to -7.82 (Fig. 7C).

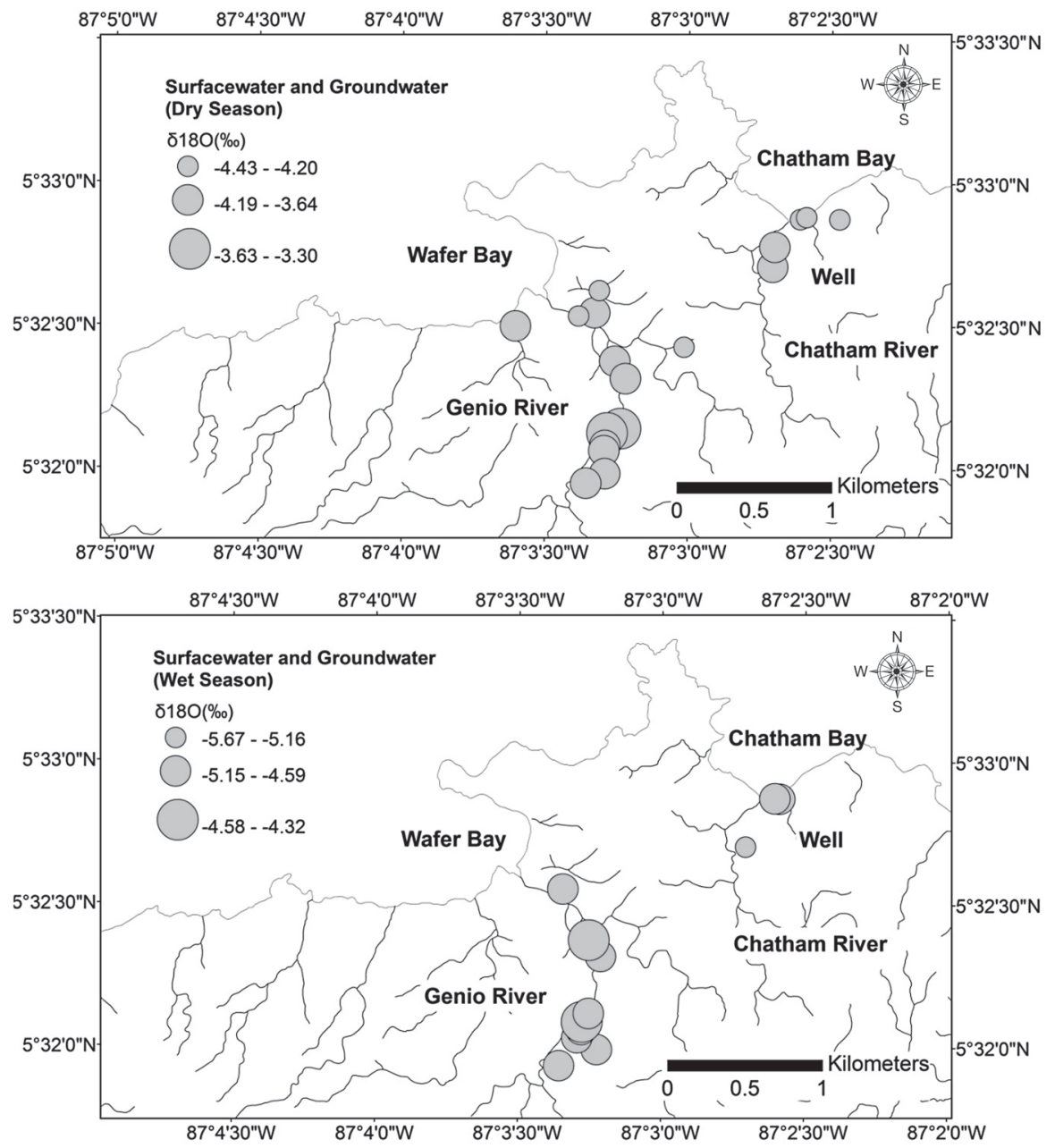

Fig. 6. $\delta^{18} \mathrm{O}(\%)$ spatial distribution in surface water and groundwater at Cocos Island during 2014. 

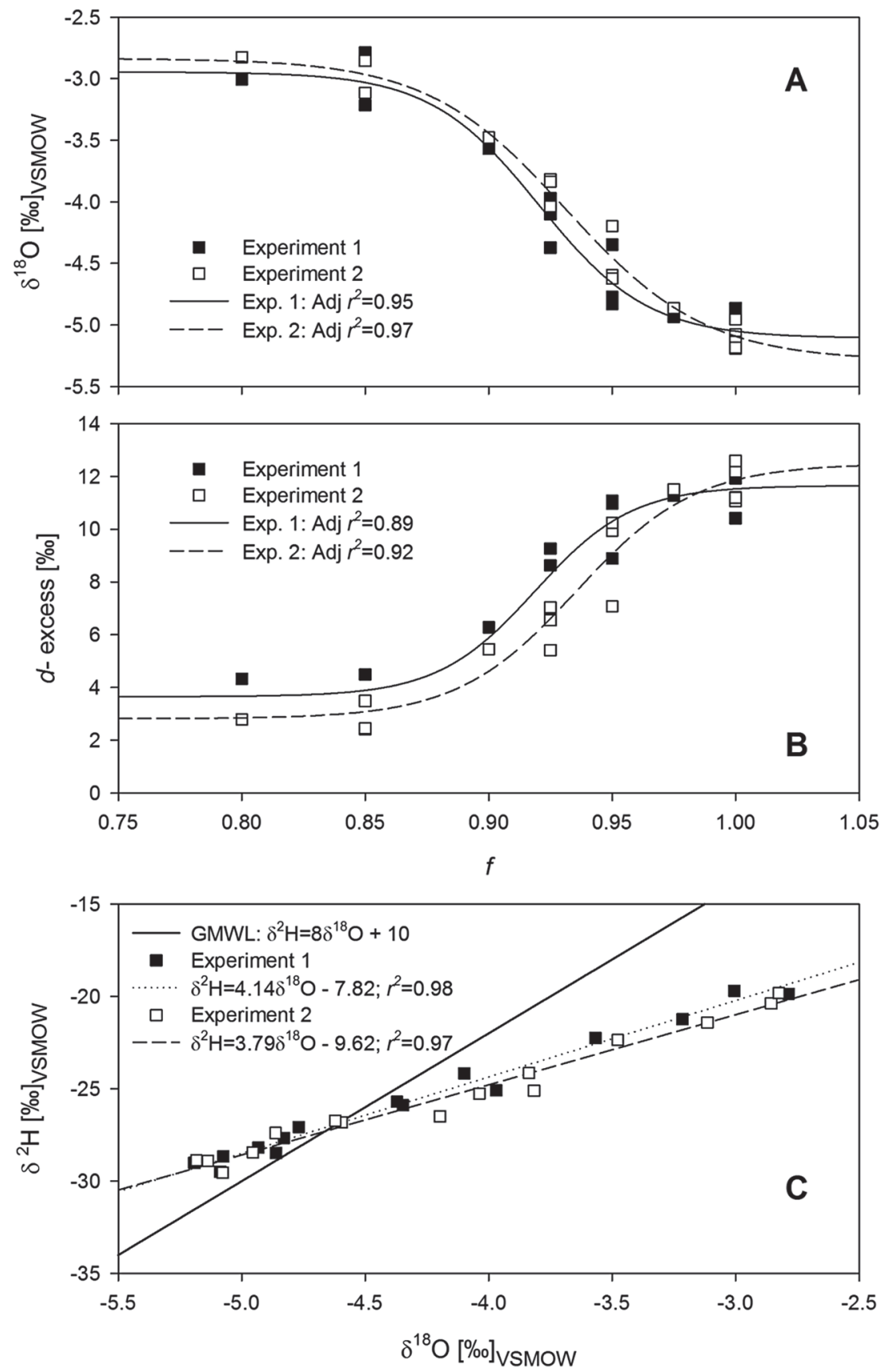

Fig. 7. (A) $\delta^{18} \mathrm{O}$ fractionation versus fraction $(f)$ of residual water. (B) $d$-excess variation versus fraction $(f)$ of residual water. (C) Meteoric water lines of pan evaporated water at Cocos Island. 


\section{DISCUSSION}

Moisture transport mechanisms: The identification of the parental moisture source of composite weekly precipitation was computed using an analysis of air mass back trajectories. Figure 8 shows the HYSPLIT trajectories for the dry (January-April) and wet season (MayNovember) at Cocos Island. The wind direction and velocity in the study region is greatly influenced by the seasonal migration of the ITCZ. Alfaro (2008) classified the diurnal wind cycles at Cocos Island in three main periods: December-April, when the synoptic southwesterly wind flux is weak and transport of northeasterly air masses prevail; May-August and September-November with a strong influence of southwesterly moisture transport. These winds trends are easily represented in Figure 8. Enriched isotope ratios are associated with northeasterly moisture transport and small precipitation events whereas more depleted isotope ratios were observed under the occurrence of southwesterly winds.

The isotopic ratios observed at Cocos Island also serve to better understand moisture transport mechanisms within the Central America continental region. Figure 9 shows a comparison of three isotope data sets in Costa Rica during 2014: Cocos Island (Pacific origin); Caribbean slope (Caribbean Sea origin) (Sánchez et al., unpublished data), and the Central Valley (Sánchez et al., unpublished data), which receives moisture inputs from both water pools through the Continental Divide. The Caribbean slope exhibits more enriched isotope ratios, with a strong right-skewed $\delta^{18} \mathrm{O}$ distribution (skewness $=-1.0$ ) in comparison to Cocos Island (skewness $=-0.36$ ) and Central Valley (skewness=-0.41) (Fig. 9). In Central America, wind direction during the dry season is controlled by a regional moisture transport mechanism, the Caribbean Low Level Jet,

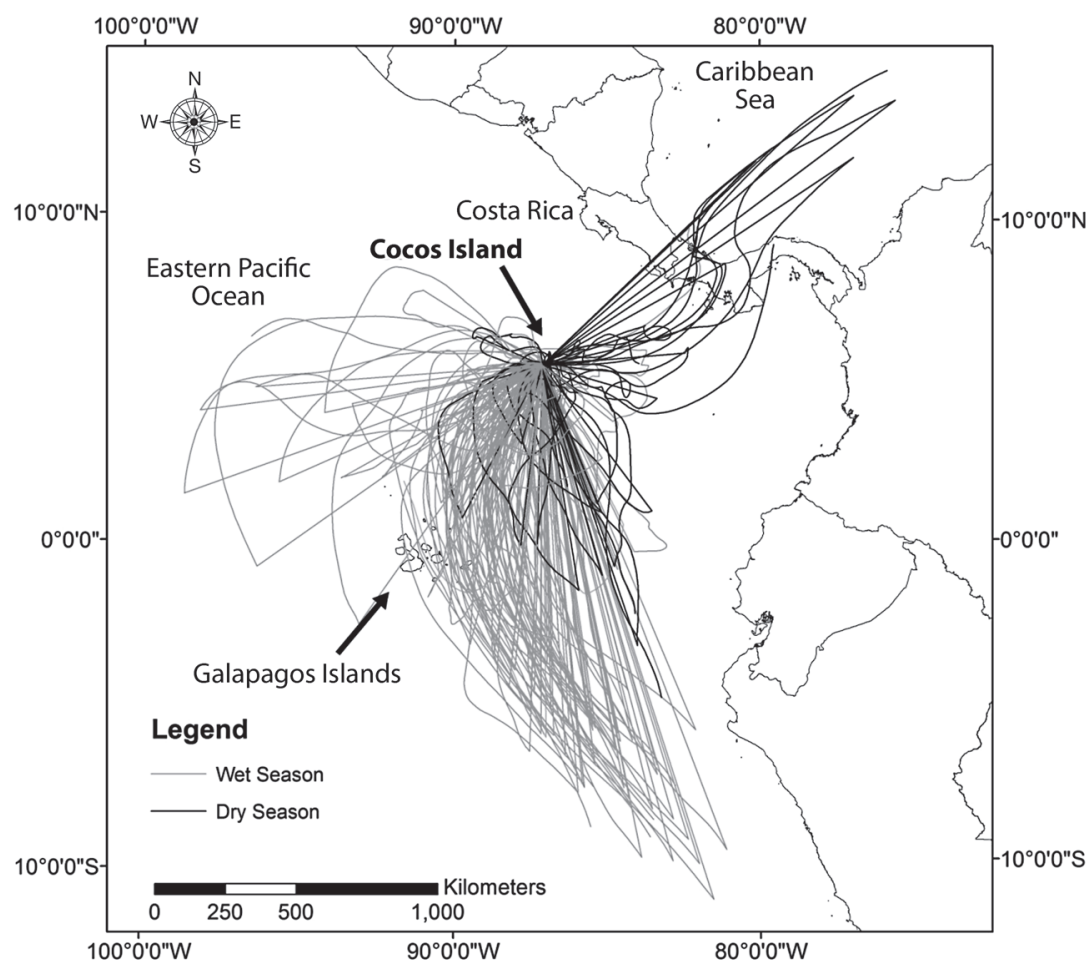

Fig. 8. Dry (black lines) and wet (gray lines) season air mass back trajectories calculated using HYSPLIT for collected samples at Cocos Island during 2014. 

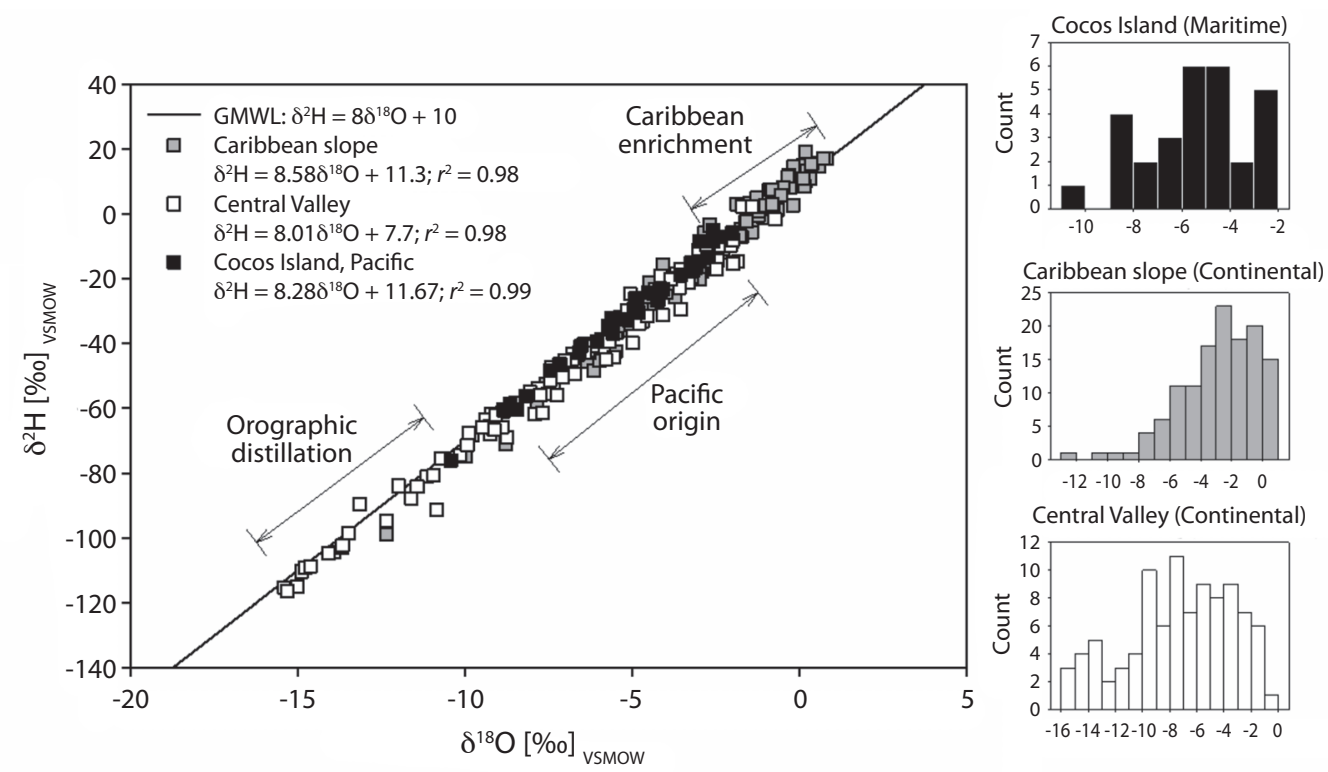

Fig. 9: Meteoric water lines and $\delta^{18} \mathrm{O}$ histograms during 2014 at Cocos Island, the Central Valley, and the Caribbean slope of Costa Rica. The Central Valley of Costa Rica receives moisture inputs from both the Pacific Ocean and the Caribbean Sea. The isotopic composition at Cocos Island serves to discriminate from orographic distillation across the Continental Divide (depleted values) and the isotopically-enriched Caribbean moisture inputs as observed in the histograms.

CLLJ (Durán-Quesada, Gimeno, Amador, \& Nieto, 2010). This water vapor transport pattern is associated with enriched rainfall events, where the recycled evapotranspiration fluxes mix with the air masses travelling along the Caribbean lowlands (Fig. 9). During the wet season, the precipitation regime is controlled by the presence of the ITCZ across Central America. When the ITCZ moves northward, cross-equatorial winds from the southern hemisphere recurve to become southwesterly and transport Pacific parental moisture to Costa Rica combined with a weakening of trade winds (Lachniet et al., 2007). As a result, intensification in the genesis and development of deep convection systems on the Pacific coast of Costa Rica occurs; generally this phenomenon is associated with the presence of the 'Chorro del Occidente Colombiano' or CHOCO jet (Fig. 8) (Durán-Quesada et al., 2010). However, when comparing both Cocos Island and the Central Valley isotopic ratios, there is a range from $-10 \% \delta^{18} \mathrm{O}$ to $-16 \% \delta^{18} \mathrm{O}$ that cannot be explained solely by the Pacific origin moisture $\left(-10 \% \delta^{18} \mathrm{O}\right.$ up to $\left.-2 \% \delta^{18} \mathrm{O}\right)$. This $-6 \% \delta^{18} \mathrm{O}$ difference can be attributed to orographic distillation of air masses lifted across the central region of the Continental Divide of Costa Rica (3432masl). Sánchez-Murillo et al. (2013) reported an altitude effect of $-2 \% / \mathrm{km}$ in precipitation of Costa Rica; therefore a $-6 \%$ depletion in $\delta^{18} \mathrm{O}$ is plausible within a $3 \mathrm{~km}$ air mass lifting from the Pacific coast towards the Central Valley of Costa Rica.

\section{CONCLUSIONS}

In this study we report the first analysis of isotope composition in precipitation, surface water, and groundwater at Cocos Island (Eastern Tropical Pacific ocean), Costa Rica. Cocos Island meteoric water line can be described as: $\delta^{2} \mathrm{H}=8.39 \cdot \delta^{18} \mathrm{O}+13.3$. In general, dry season rainfall events were associated with enriched isotope ratios with a northeasterly dominant origin whereas wet season rainfall events exhibited a notable depletion when the Intertropical Convergence Zone reaches Costa Rica 
by the beginning of May. During the wet season, the dominant air mass trajectories exhibited a southwesterly direction. Small seasonal variations were observed in the isotopic composition of surface water throughout the year with mean values ranging from $-3.9 \% \delta^{18} \mathrm{O}$ (dry season) up to $-4.8 \% \delta^{18} \mathrm{O}$ (wet season). Groundwater samples exhibited a similar trend with more depleted composition during the wet season $\left(-5.2 \% \delta^{18} \mathrm{O}\right.$ and $\left.-29.8 \% \delta^{2} \mathrm{H}\right)$. Overall, the marine isotopic composition measured in meteoric water at Cocos Island serves to better delineate the isotopic contribution of Pacific moisture towards the Central America Isthmus as well as provides a valuable isotopic reference to discriminate from orographic distillation and Caribbean enriched rainfall inputs in continental studies.

\section{ACKNOWLEDGMENTS}

This study was partially supported by International Atomic Energy Agency grant CRP-19747 to RSM under the initiative "Stable isotopes in precipitation and paleoclimatic archives in tropical areas to improve regional hydrological and climatic impact models". The authors would like to thank the collaboration of Cocos Island Marine Conservation Area and the National Conservation Areas Systems for providing transportation to the island, research facilities to conduct two field expeditions, and access to daily meteorological data. We would like to recognize the valuable work of all park rangers whom collaborated with field sampling campaigns, collection of weekly precipitation samples, and shipping of samples to the Port of Puntarenas and San José, Costa Rica.

\section{RESUMEN}

El uso de isótopos estables, $\delta^{2} \mathrm{H}$ y $\delta^{18} \mathrm{O}$, ha generado novedoso conocimiento en estudios hidrológicos, aplicaciones ecológicas, variabilidad climática y en la reconstrucción de registros paleo-climáticos. Sin embargo, información sobre la composición isotópica en ambientes marinos tropicales es generalmente muy escasa en la región del istmo centroamericano. Este estudio presenta la primera caracterización isotópica en precipitación, aguas superficiales y subterráneas en la Isla del Coco, Costa Rica, en la región del Océano Pacífico Oriental. La línea meteórica de la Isla del Coco es definida como: $\delta^{2} \mathrm{H}=8.39 \cdot \delta^{18} \mathrm{O}+13.3 ; \mathrm{r}^{2}=0.98(\mathrm{n}=29)$. Los eventos de precipitación en la época seca oscilan desde $-4.9 \%$ o $\delta^{18} \mathrm{O}$ hasta $-2.4 \% \delta^{18} \mathrm{O}$ con un promedio de exceso de deuterio de $13.2 \%$. Al inicio de Mayo, la Zona de Convergencia Intertropical se sitúa sobre Costa Rica resultando en un notable empobrecimiento de la composición isotópica (hasta -10.4 $\%_{0} \delta^{18} \mathrm{O}$ y $\left.-76.2 \% \delta^{2} \mathrm{H}\right)$. Durante la época lluviosa, la composición de $\delta^{18} \mathrm{O}$ promedia $-6.1 \%{ }_{0} \delta^{18} \mathrm{O}$ y $-38.5 \%{ }^{2} \mathrm{H}$ con un exceso de deuterio promedio de $9.9 \%$. Las trayectorias de masas de aire del modelo HYSPLIT indican una fuerte influencia en el origen de la precipitación de dos principales mecanismos de transporte de humedad: vientos alisios (Enero-Mayo) y viento del suroeste (Mayo-Noviembre). Mínima variación fue observada en la composición isotópica de aguas superficiales durante el año con valores promedios desde $-3.9 \% \delta^{18} \mathrm{O}$ (época seca, $\mathrm{n}=19$ ) hasta $-4.8 \% \delta^{18} \mathrm{O}$ (época lluviosa, $\mathrm{n}=13$ ). Las muestras de agua subterránea presentaron una tendencia similar con valores más empobrecidos durante la época lluviosa $\left(-5.2 \% \delta^{18} \mathrm{O}\right.$ y $\left.-29.8 \% \delta^{2} H\right)$. En general, la composición isotópica en el ambiente marino de la Isla del Coco en aguas meteóricas es útil para delinear la contribución de humedad proveniente del Océano Pacífico Oriental hacia el istmo centroamericano. Asimismo, provee una valiosa referencia isotópica en la separación de los efectos de la destilación orográfica y el aporte de humedad enriquecida del Mar Caribe en estudios continentales.

Palabras Clave: Isla del Coco, Océano Pacífico Oriental, Zona de Convergencia Intertropical, isótopos estables, trayectorias HYSPLIT.

\section{REFERENCES}

Acuña-González, J., García-Céspedes, J., Gómez-Ramírez, E., Vargas, J.A., \& Cortés, J. (2008). Parámetros físico-químicos en aguas costeras de la Isla del Coco, Costa Rica (2001-2007). Revista de Biología Tropical, 56(Supplement 2), 49-56.

Aggarwal, P. K., Alduchov, O. A., Froehlich, K. O., Araguas-Araguas, L. J., Sturchio, N. C., \& Kurita, N. (2012). Stable isotopes in global precipitation: A unified interpretation based on atmospheric moisture residence time. Geophysical Research Letters, 39, L11705. doi:10.1029/2012GL051937.

Alfaro, E. J. (2008). Ciclo diario y anual de variables troposféricas y oceánicas en la Isla del Coco, Costa Rica. Revista de Biología Tropical, 56(Supplement 2), 19-29.

Alvarado, J. J., \& Chiriboga, A. (2008). Distribución y abundancia de equinodermos en las aguas someras de la Isla del Coco, Costa Rica (Pacífico Oriental). 
Revista de Biológia Tropical, 56(Supplement 2), 99-111.

Amador, J. A., Alfaro, E. J., Lizano, O. G., \& Magaña, V. O. (2006). Atmospheric forcing of the eastern Pacific: A review. Progress in Oceanography, 69, 101-142.

Araguás-Araguás, L., Froehlich, K., \& Rozanski, K. (1998). Stable isotope composition of precipitation over southeast Asia. Journal of Geophysical Research, 103, 28721-28742.

Araguás-Araguás, L., Froehlich, K., \& Rozanski, K. (2000). Deuterium and oxygen-18 isotope composition of precipitation and atmospheric moisture. Hydrological Processes, 14, 230-244.

Berden, G., Peeters, R., \& Meijer, G. (2000). Cavity ringdown spectroscopy: Experimental schemes and applications. International Review in Physical Chemistry, 19, 565-607.

Bernan, E. S. F., Levin, N. E., Landais, A., Li, S., \& Owano, T. (2013). Measurement of $\delta^{18} \mathrm{O}, \delta^{17} \mathrm{O}$, and ${ }^{17} \mathrm{O}$ - excess in water by Off-Axis Integrated Cavity Output Spectroscopy and Isotope Ratio Mass Spectrometry. Analytical Chemistry, 85,10392-10398.

Birkel, C., Soulsby, C., Tezlaff, D., Dunn, S., \& Spezia, L. (2012). High-frequency storm event isotope sampling reveals time-variant transit time distributions and influence of diurnal cycles. Hydrological Processes, 26, 308-316.

Bowen, G. J., \& Revenaugh, J. (2003). Interpolating the isotopic composition of modern precipitation. Water Resources Research, 39, 1299. doi:10.1029/2003WR002086.

Breedy, O., \& Cortés, J. (2008). Octocorals (Coelenterata: Anthozoa: Octocorallia) of Isla del Coco, Costa Rica. Revista de Biología. Tropical, 56(Supplement 2), 71-77.

Cappa, C. D., Hendricks, M. B., DePaolo, D. J., \& Cohen, R. C. (2003). Isotopic fractionation of water during evaporation. Journal of Geophysical Research: Atmospheres (1984-2012), 108(D16).

Castillo, P., Batiza, R., Vanko, D., Malavassi, E, Barquero, J, \& Fernández, E. (1988). Anomalously young volcanoes on old hot-spot traces: I. Geology and petrology of Cocos Island. Bulletin of the Geological Society of America, 100, 1400-1414.

Cobb, K. M., Adkins, J. F., Partin, J. W., \& Clark, B. (2007). Regional-scale climate influences on temporal variation of rainwater and cave dripwater oxygen isotopes in northern Borneo. Earth and Planetary Science Letters, 263, 207-220.

Cortés, J. (2008). Historia de la investigación marina en la Isla del Coco, Costa Rica. Revista de Biología Tropical, 56(Supplement 2), 1-18.

Craig, H. (1961). Isotopic variations in meteoric waters. Science, 133, 1702-1703.
Draxler, R. R., \& Rolph, G. D. (2014). HYSPLIT (Hybrid Single-Particle Lagrangian Integrated Trajectory). Model access via NOAA ARL READY. NOAA Air Resources Laboratory, Silver Spring, Maryland, USA. Retrieved from http://ready.arl.noaa.gov/HYSPLIT.php

Durán-Quesada, A. M., Gimeno, L., Amador, J. A., \& Nieto, R. (2010). Moisture sources for Central America: Identification of moisture sources using a Lagrangian analysis technique. Journal of Geophysical Research, 115, D05103. doi:10.1029/2009JD012455.

Fernández, C. (2008). Flora marina del Parque Nacional Isla del Coco, Costa Rica, Pacífico Oriental Tropical. Revista de Biología Tropical, 56(Supplement 2), 57-69.

Gupta, P., Noone, D., Galewsky, J., Sweeney, C., \& Vaughn, B.H. (2009). Demonstration of high-precision continuous measurements of water vapor isotopologues in laboratory and remote field deployments using wavelength-scanned cavity ring-down spectroscopy (WS-CRDS) technology. Rapid Communications in Mass Spectrometry, 23, 2534-2542.

Guzman, H. M., \& Cortés, J. 2006. Reef recovery 20 years after the 1982-1983 El Niño massive mortality. Marine Biology, 151, 401-411.

Ichiyanagi, K., \& Yamanaka, M. D. (2005). Interannual variation of stable isotopes in precipitation at Bangkok in response to El Niño Southern Oscillation. Hydrological Processes, 19, 3413-3423.

Ishizaki, Y., Yoshimura, K., Kanae, S., Kimoto, M., Kurita, N., \& Oki, T.(2012). Interannual variability of $\mathrm{H} 218 \mathrm{O}$ in precipitation over the Asian monsoon region. Geophysical Research, 117, D16308. doi:10.1029/2011JD015890.

International Atomic Energy Agency (IAEA). (2014). IAEA/GNIP Precipitation Sampling Guide. Vienna, Austria.

Johnson, K. R., \& Ingram, B. L. (2004). Spatial and temporal variability in the stable isotope systematics of modern precipitation in China: implications for paleoclimatic reconstructions. Earth and Planetary Science Letters, 220, 365-377.

Lachniet, M. (2009a). Climatic and environmental controls on speleothem oxygen-isotope values. Quaternary Science Reviews, 28(5-6), 412-432. doi:10.1016/j. quascirev.2008.10.021.

Lachniet, M. S. (2009b). Sea surface temperature control on the stable isotopic composition of rainfall in Panama. Geophysical Research Letters, 36, L03701. doi:10.1029/2008GL036625.

Lachniet, M. S., \& Patterson, W. P. (2009). Oxygen isotope values of precipitation and surface waters in northern Central America (Belize and Guatemala) are 
dominated by temperature and amount effects. Earth and Planetary Science Letters, 284, 435-446.

Lachniet, M., Paterson, W. P., Burns, S., Asmerom, Y., \& Polyak, V. (2007). Caribbean and Pacific moisture sources on the Isthmus of Panama revealed from stalagmite and surface water $\delta^{18} \mathrm{O}$ gradients. Geophysical Research Letters, 34, L01708. doi:10.1029/2006GL028469.

McGlynn, B., McDonnel, J. J., \& Brammer, D. D. (2002). A review of the evolving perceptual model of hillslope flowpaths at the Maimai catchments, New Zealand. Journal Hydrology, 257, 1-26.

Moerman, J. W., Cobb, K. M., Adkins, J. F., Sodemann, H., Clark, B., \& Tuen, A. A. (2013). Diurnal to interannual rainfall $\delta^{18} \mathrm{O}$ variations in northern Borneo driven by regional hydrology. Earth and Planetary Science Letters, 369-370, 108-119.

Montoya, M. (2008). Aves marinas de la Isla del Coco, Costa Rica, y su conservación. Revista de Biología Tropical, 56(Supplement 2), 133-149.

Munksgaard, N. C., Wurster, C. M., Bass, A., \& Bird, M. I. (2012). Extreme short-term stable isotope variability revealed by continuous rainwater analysis. Hydrological Processes, 26, 3630-3634.

National Oceanic and Atmospheric Administration (NOAA) (2014). El Niño/Southern Oscillation (ENSO) Diagnostic Discussion. Washington, DC: US Government. Retrieved from http://www.cpc.ncep. noaa.gov/products/analysis_monitoring/enso_advisory/ensodisc.html

Panarello, H. O., \& Dapeña, C. (2009). Large scale meteorological phenomena, ENSO and ITCZ, define the Paraná River isotope composition. Journal of Hydrology, 365. 105-112.

Risi, C., Noone, D., Frankenberg, C. \& Worden, J. (2013). Role of continental recycling in intraseasonal variations of continental moisture as deduced from model simulations and water vapor isotopic measurements. Water Resources Research, 49, 4136-4156.

Rozanski, K., Sonntag, C., \& Münnich, K. O. (1982). Factors controlling isotopic composition of European precipitation. Tellus, 34, 142-150.

Rojas, W., \& Alvarado, G. E. (2012). Geología y contexto geotectónico de la Isla del Coco y la zona marítima frente al Pacífico central de Costa Rica. Rev. Biol. Trop, 60(Supplement 3), 15-32.

Sánchez-Murillo, R., Esquivel-Hernández, G., Welsh, K., Brooks, E. S., Boll, J., Alfaro-Solís, R., \& ValdésGonzález, J. (2013). Spatial and temporal variation of stable isotopes in precipitation across Costa Rica: an analysis of historic GNIP records. Open Journal of Modern Hydrology, 3(4). doi:10.4236/ ojmh.2013.34027.

Sánchez-Murillo, R., Brooks, E. S., Elliot, W. J., \& Boll, J. (2015). Isotope hydrology and baseflow geochemistry in natural and human-altered watersheds in the Inland Pacific Northwest, USA. Stable Isotopes in Environmental and Health Studies, 51, 231-254.

Soderberg, K., Good, S. P., O’Connor, M., Wang, L., Ryan, K., \& Caylor, K. K. (2013). Using atmospheric trajectories to model the isotopic composition of rainfall in central Kenya. Ecosphere, 4(3), 33. doi: 10.1890/ ES12-00160.1.

Speed, M., Tezlaff, D., Soulsby, C., Hrachowitz, M., \& Waldron, S. (2010). Isotopic and geochemical tracers reveal similarities in transit times in contrasting mesoscale catchments. Hydrological Processes, 24, 1211-1224.

Sturm, C., Zhang, Q., \& Noone, D. (2010). An introduction to stable water isotopes in climate models: benefits of forward proxy modelling for paleoclimatology. Climate of the Past, 6, 115-129.

Tezlaff, D., \& Soulsby, C. (2008). Towards simple approaches for mean residence time estimation in ungauged basins using tracers and soil distributions. Journal of Hydrology, 363, 60-74.

Vuille, M., \& Wermer, M. (2005). Stable isotopes in precipitation recording South American summer monsoon and ENSO variability: Observations and model results. Climate Dynamics, 25, 401-413.

Vuille, M., Bradley, R. S., \& Keimig, F. (2000). Interannual climate variability in the Central Andes and its relation to tropical Pacific and Atlantic forcing. Journal of Geophysical Research, 105, 12447-12460.

Vuille, M., Bradley, R. S., Healy, R., Werner, M., Hardy, D. R., Thompson, L. G., \& Keimig, F. (2003). Modeling $\delta^{18} \mathrm{O}$ in precipitation over the tropical Americas 2: Simulation of the stable isotope signal in Andean ice cores. Journal of Geophysical Research, 108, NO. D6, 4175. doi:10.1029/2001JD002039.

Wassenaar, L. I., Athanasopoulos, P., \& Hendry, M. J. (2011). Isotope hydrology of precipitation, surface and ground waters in the Okanagan Valley, British Columbia, Canada. Journal of Hydrology, 411, 37-48.

Wen, X. F., Sun, X. M., Zhang, S. C., Yu, G. R., Sargent, S. D., \& Lee, X. (2008). Continuous measurement of water vapor $\mathrm{D} / \mathrm{H}$ and ${ }^{18} \mathrm{O} /{ }^{16} \mathrm{O}$ isotope ratios in the atmosphere. Journal of Hydrology, 349, 489-500. 